\title{
Intracellular enzymatic histochemistry of the human stomach with special reference to atrophic gastritis
}

\author{
H. RAGINS AND M. DITTBRENNER \\ From the Gastroenterology Research Laboratory of the Department of Surgery \\ of the Albert Einstein College of Medicine, Bronx 61, New York, U.S.A.
}

EDITORIAL SYNOPSIS These studies demonstrate an altered pattern of cellular enzymic activity in patients with atrophic gastritis. The interesting and orginal supposition is put forward that this may possibly represent a change in function from a primarily secretory mucosa to a primarily absorptive epithelium.

The purpose of this study was to gain a new insight into the intracellular function of normal and abnormal gastric mucosa for correlation with clinical and pathological information. Although at least 20 different enzymes have been investigated histochemically in the stomach of man and several animals during the last nine years (summarized by Ragins, Dittbrenner, and Diaz, 1964) the vast majority of the techniques employed in these investigations used completely unfixed tissues. In an effort to preserve the intracellular structure as well as the enzymatic activity, the present study used tissues which were fixed immediately in cold neutral formalin for 24 hours, as suggested by Novikoff (1960).

The most striking finding in this study was a marked increase in thiamine pyrophosphatase activity in the abnormal cells of atrophic gastritis.

\section{METHODS}

The mucosal specimens were obtained from volunteer patients equally divided between the sexes and ranging in age from 17 to 92 years (average 59 years). They were selected from the general surgical wards of the Bronx Municipal Hospital Center with the intent of studying a series of normals. If there was an epigastric complaint, a normal barium $x$-ray study of the stomach was required. Secretory data were not obtained. This elderly group of patients frequently had several medical and surgical diseases. In considering their dominant surgical problem, $80 \%$ of them had one of the following: (1) intra-abdominal carcinoma, (2) biliary tract disease, (3) duodenal ulcer, (4) hernia, and (5) diabetic gangrene.

Mucosal specimens obtained from the stomach of 49 human subjects with no known gastric disease were studied with four enzymatic methods. Three of these methods are said to stain specific cytoplasmic organelles: the acid phosphatase method (PbS) of Gomori (1950) marks the lysosomes (Essner and Novikoff, 1960); the thiamine pyrophosphatase (T.T.P.-ase) method of Novikoff and Goldfischer (1961) stains the Golgi apparatus; and the $\mathrm{NADH}_{2}{ }^{1}$ tetrazolium reductase method of Novikoff, Shin, and Drucker (1961) designates the mitochondria. The fourth method demonstrates acid phosphatase activity by the azo-dye direct coupling technique of Barka and Anderson (1963). Red granular deposits are formed in the cytoplasm which do not conform to the presumed lysosomes of the PbS method.

The biopsy material was taken from the corpus of the empty stomach either at the time of laparotomy or with Wood's flexible gastric biopsy tube. A sample for routine histology (Lillie, 1954) was fixed in formalin and processed in the usual manner for paraffin sections. The specimen for enzymatic studies was immediately placed in iced Baker's formol calcium and fixed for 24 hours at $4^{\circ} \mathrm{C}$.

After fixation, sections were cut on a freezing microtome at $7.5 \mu$ into iced distilled water. The acid phosphatase incubations were begun immediately. The remaining enzyme studies were completed by the following day. In the interim the sections were stored in distilled water at $4^{\circ} \mathrm{C}$. as recommended by Novikoff and Goldfischer (1961).

The details of the enzymatic methods are as follows:

1 ACID PHOSPHATASE (PbS METHOD) The Gomori (1950) medium was used. The free floating sections were incubated for 30 minutes at $37^{\circ} \mathrm{C}$., washed in distilled water, coloured in dilute ammonium sulphide solution, washed again in water, and then mounted in Gurr's medium or glycerogel. The discrete black granules of $\mathrm{PbS}$ seen in the cytoplasm represent the product of the acid phosphatase activity which is thought to be located in the lysosomes.

${ }^{1} \mathrm{NADH}_{2}$, nicotinamide adenine dinucleotide reduced $=$ D.P.N.H. 
2 ACID PHOSPhatase (AZO-DYE METHOD) The substrate was prepared as described by Barka and Anderson (1963). The sections were premounted on a slide with a drop of albumin. The incubation period was 90 minutes at $37^{\circ} \mathrm{C}$. and after dehydration the cover slips were applied with Permount. With this method, acid phosphatase activity is recognized in the cytoplasm as a deep red orange stain against the green counter stain (methyl green).

3 THIAMINE PYROPHOSPHATASE (T.T.P.-ASE) The substrate was prepared exactly as described by Novikoff and Goldfischer (1961). Free floating sections were incubated for 45 minutes at $37^{\circ} \mathrm{C}$., washed in distilled water, coloured in dilute ammonium sulphide solution, washed again in water, and mounted in Gurr's medium or glycerogel. The Golgi apparatus in the perinuclear area is stained brown-black.

$4 \mathrm{NADH}_{2}$ TETRAZOLIUM REDUCTASE The substrate was prepared as described by Novikoff et al. (1961). Free floating sections were incubated for five minutes at $37^{\circ} \mathrm{C}$., washed in distilled water, and then mounted in Gurr's medium or glycerogel. The mitochondria are stained a dense blue. It was necessary to store these sections in the deep freeze, because, if they remained at room temperature for a few days, large blue granules appeared in the 'test' as well as the 'control' sections.

Control sections, incubated in media containing no substrate, were run with all procedures.

In the preliminary studies of these enzymatic methods with both the canine and human stomach, incubation periods were varied in the acid phosphatase (PbS) method from 15 to 60 minutes, in the acid phosphatase (azo-dye) method from 30 to 90 minutes, in the T.P.P.-ase method from 15 to 105 minutes, and in the $\mathrm{NADH}_{2}$ tetrazolium reductase method from three to 15 minutes. Increased incubation resulted in increased intensity of staining of the products of the enzymatic activity, but it did not increase the number of deposits which appeared.

The slides were reviewed independently by both authors and the activity found in each major cell type was grossly quantitated. Currently few histochemical methods can be made strictly quantitative, but it is nearly always possible to make semi-quantitative estimations by one or other of the accepted techniques.

\section{RESULTS}

When it became apparent from examination of the histological sections that the majority of these patients had some degree of gastritis, the specimens were grouped into three categories: (1) normal, in which the mucosa had normal glandular elements and only slight infiltration with inflammatory cells; (2) moderate gastritis, in which the glands retained most of their differentiated cells but there was moderate infiltration of the lamina propria with inflammatory cells; (3) severe gastritis when the glands consisted of mucous cells, goblet cells, and sometimes Paneth cells and the lamina propria was densely infiltrated with inflammatory cells.

We tried to relate the histological appearance with the clinical parameters of age, sex, and primary disease. Only age correlated well with the severity of the metaplasia. Although these patients were selected because they had no known gastric disease, on histological examination $53 \%$ of them had moderate to severe gastritis. (In a series of 97 necropsies, Hebbel (1949) noted a similar incidence of chronic gastritis in otherwise normal stomachs.)

A typical normal human gastric mucosa is demonstrated in Figures 1 to 5. The enzymatic activities shown by the two acid phosphatase methods were generally similar in distribution. Moderate numbers of discrete granules, mainly in the zymogen cells, were found frequently with the $\mathrm{PbS}$ method for acid phosphatase activity (Fig. 1). With the azo-dye method, the activity was moderate in the zymogen cells and slight in the parietal cells (Fig. 2). $\mathbf{N A D H}_{2}$ tetrazolium reductase activity demonstrated the mitochondria-rich parietal cells well (Fig. 3). The large cytoplasmic spaces devoid of staining may represent intracellular secretory canaliculi. The very prominent granules seen in Fig. 3 were distinct from the mitochondria and not present in every cell. These granules did not appear when tetra-nitro BT was substituted for nitro-BT in the substrate and the oil-red-O fat stain showed deposits that seemed to correspond with them. These two observations suggest that the deep blue granules are lipid in nature (Novikoff, 1963), but their origin is unknown. The other glandular cells show very faint $\mathrm{NADH}_{2}$ tetrazolium reductase activity (Fig. 4). In the normal mucosal cells there was generally no T.P.P.-ase activity (Fig. 5).

The range of enzymatic activity of the individual

TABLE I

GROSS QUANTITATION OF ENZYMATIC ACTIVITIES IN THE INDIVIDUAL CELL TYPES IN THE NORMAL HUMAN GASTRIC MUCOSA (21 CASES)

\begin{tabular}{|c|c|c|c|c|}
\hline Enzyme & Mucous Surface Cells & Mucous Neck Cells & Parietal Cells & Zymogen Cells \\
\hline $\begin{array}{l}\text { Acid phosphatase (PbS) } \\
\text { Acid phosphatase (azo-dye) } \\
\text { T.P.P.-ase } \\
\text { NADH, tetrazolium reductase }\end{array}$ & $\begin{array}{l}0^{1}(0-2+)^{2} \\
\text { Trace }(0-2+) \\
0(0-1+) \\
\text { Trace }\end{array}$ & $\begin{array}{l}1+(0-1+) \\
\text { Trace }(0-1+) \\
\text { Trace }\end{array}$ & $\begin{array}{l}\text { Trace }(0-1+) \\
\frac{1+(0-3+)}{3+}\end{array}$ & $\begin{array}{l}3+(1-4+) \\
4+(1-4+) \\
0(0-1+) \\
\text { Trace }\end{array}$ \\
\hline
\end{tabular}

'The mode

'The range 


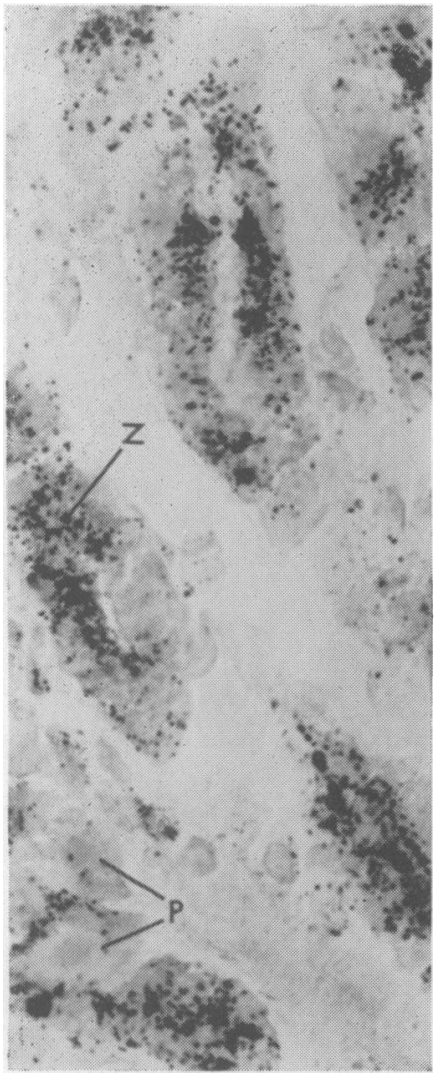

FIG. 1.

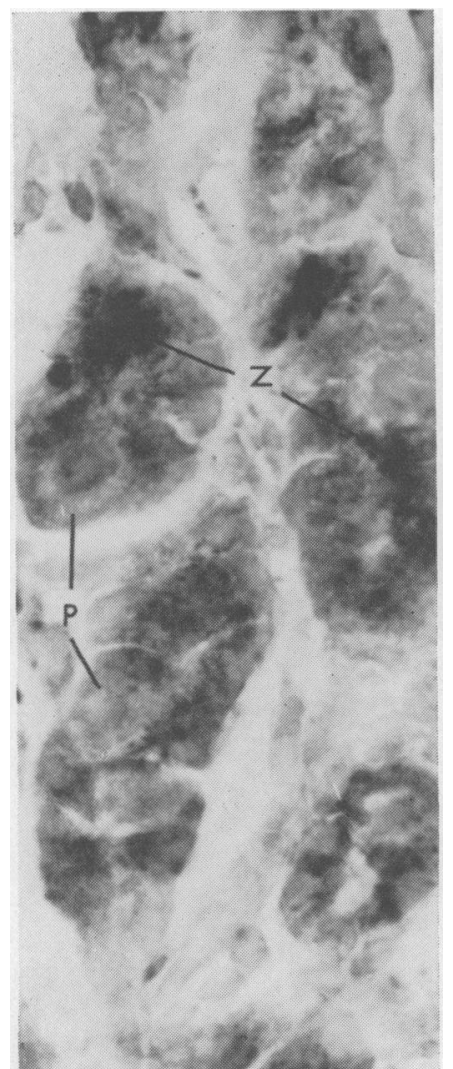

FIG. 2.

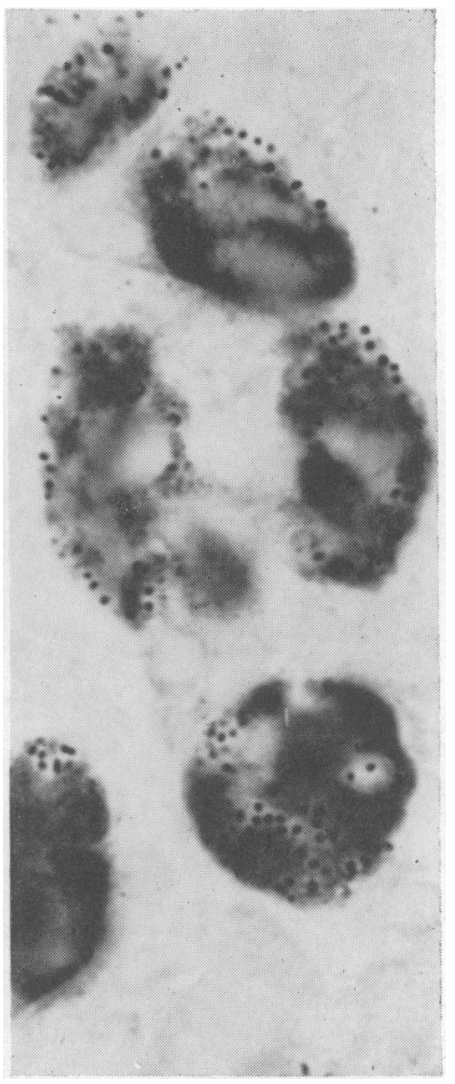

FIG. 3.

FIG. 1. Normal mucosa: acid phosphatase (PbS) method. The strongest activity is in the zymogen cells $(Z)$. Only scanty activity is present in the parietal cells $(P)$ and the mucous cells (not shown). $\times 532$.

FIG. 2. Normal mucosa: acid phosphatase, azo-dye method. The activity is strongest in the zymogen cells $(Z)$ although some is present in the parietal cells $(P) . \times 532$.

FIG. 3. Normal mucosa: parietal cells: $\mathrm{NADH}_{2}$ tetrazolium reductase. The wide spaces between the mitochondrial staining probably represent intracellular secretory canaliculi. The prominent (deep blue) granules represent lipid droplets. $\times 1,053$.

cell types in the normal mucosa is summarized in Table I. The histochemical staining patterns of the tissue obtained at laparotomy did not differ significantly from the peroral tube specimens. Thus a variety of anaesthetics, premedications, and the presence of an intragastric tube did not appear to alter the enzymatic activities which we studied.

The mucosa showing gastritis of varying degree was of particular interest. An increase in T.P.P.-ase activity was seen mainly in the foveolar mucous surface cells. The more severe the gastritis, the more intense was the T.P.P.-ase activity. The $\mathrm{NADH}_{2}$ tetrazolium reductase activity of the mucosa as a whole decreased as the parietal cells disappeared. The acid phosphatase activity shown by both methods was moderately strong.
A specimen with severe chronic atrophic gastritis (proven by the lack of parietal cells, Fig. 6) demonstrates intense T.P.P.-ase activity in the Golgi zone (Fig. 7) of the remaining primitive cells. The three patients with focal gastritis all clearly demonstrated the specificity of this reaction. Figures 8 to 10 illustrate this point. Thus, the normal glands are sharply delineated by the $\mathrm{NADH}_{2}$ tetrazolium reductase activity from the metaplastic gastritis glands (Fig. 8). Figure 9 shows the strong activity in the foveolar mucous surface cells of the atrophic glands and Fig. 10 illustrates the absence of T.P.P.-ase activity in the adjacent normal glands.

\section{DISCUSSION}

Very little is known about the aetiology or patho- 


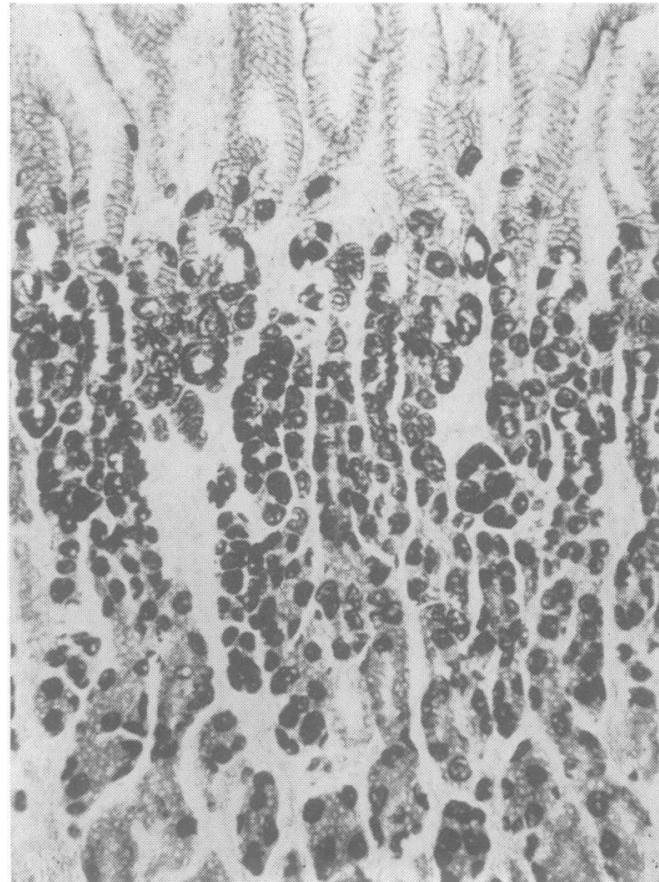

FIG. 4.

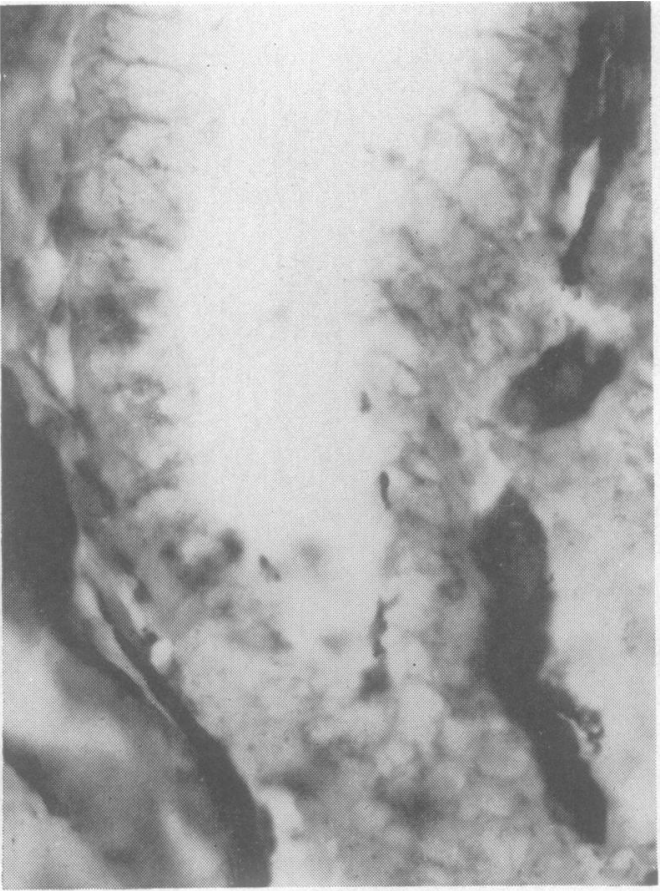

FIG. 5.

fIG. 4. Normal mucosa: $\mathrm{NADH}_{2}$ tetrazolium reductase. The parietal cells are deeply stained. The other glandular cells show very faint activity. $\times 90$.

FIG. 5. Normal mucosa: T.T.P.-ase. Foveolar area. In the normal mucosal cells there was generally no activity. $\times 90$

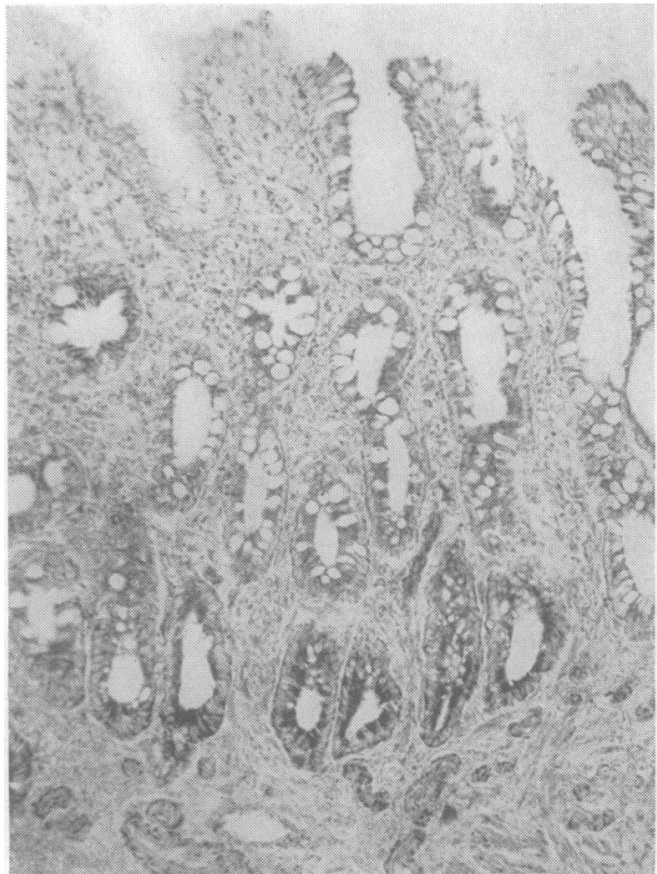

FIG. 6.

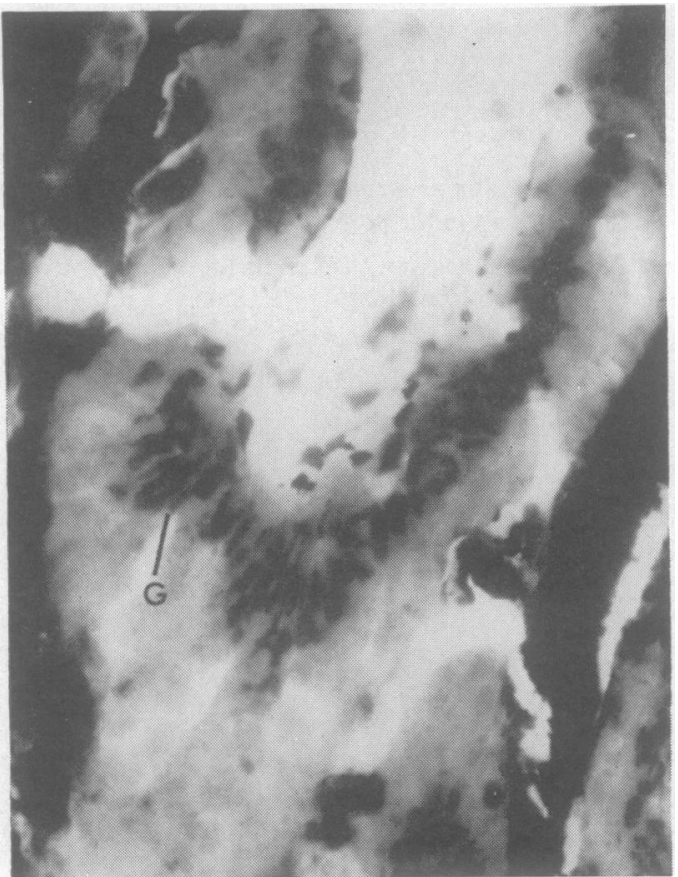

FIG. 7.

FIG. 6. Severe atrophic gastritis: $\mathrm{NADH}_{2}$ tetrazolium reductase. Parietal cells are absent. Intestinal metaplasia with goblet cells is apparent. $\mathrm{NADH}_{2}$ tetrazolium reductase activity is minimal. $\times 90$.

FIG. 7. Severe atrophic gastritis: T.P.P.-ase. Foveolar area. Heavy activity is seen in the Golgi zone $(G)$ of the metaplastic cells. $\times 494$. 


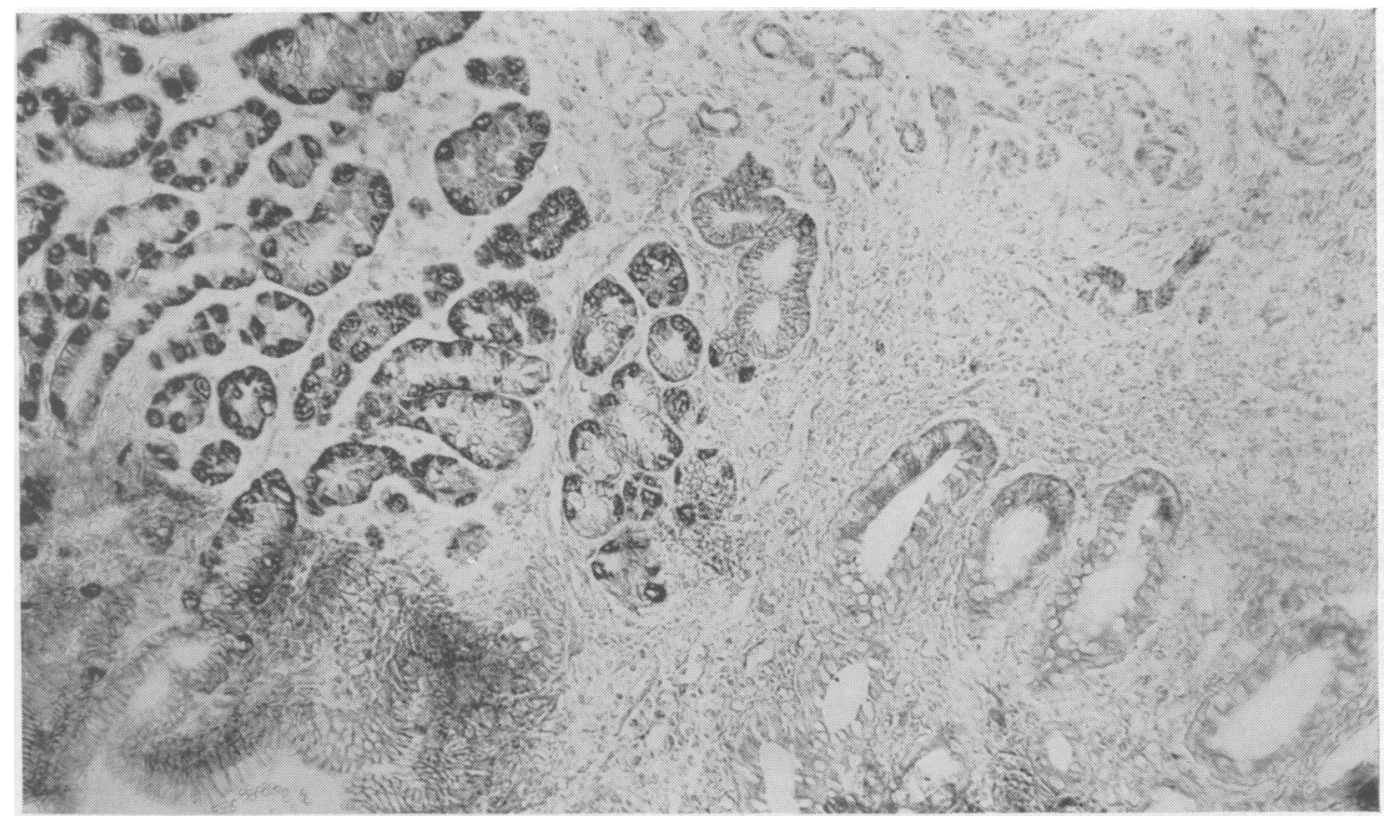

FIG. 8. Focal atrophic gastritis: $\mathrm{NADH}_{2}$ tetrazolium reductase. The normal glands containing parietal cells are sharply delineated from the metaplastic area. $\times 112$.

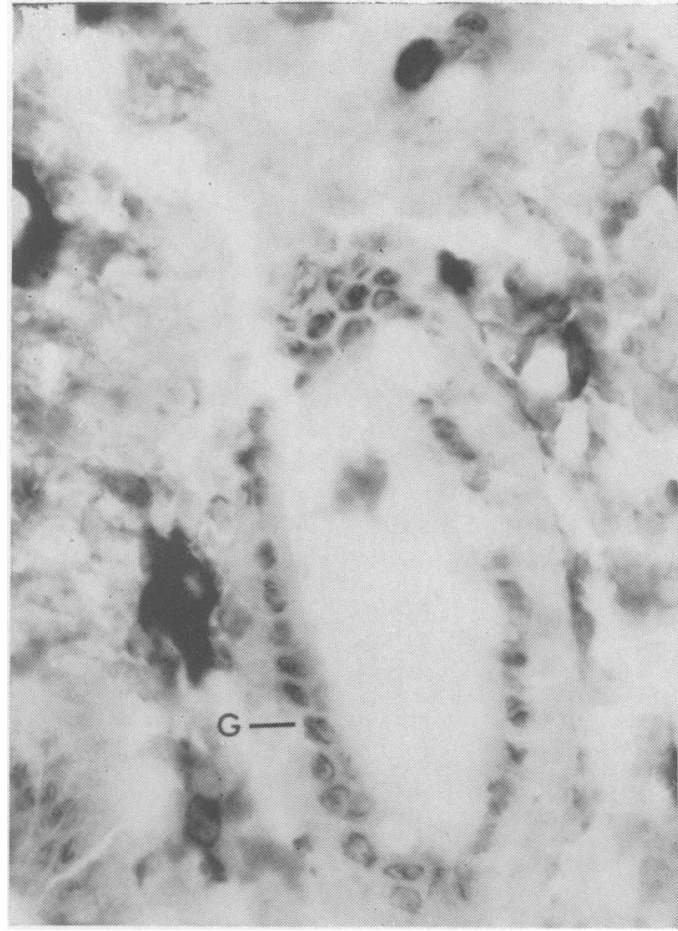

FIG. 9.

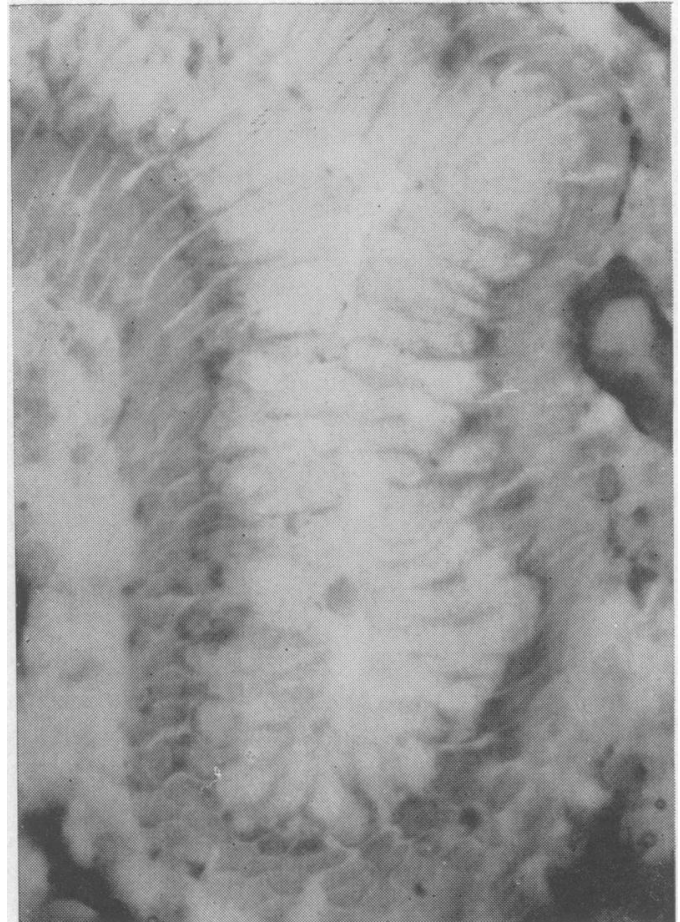

FIG. 10.

FIG. 9. Focal atrophic gastritis in abnormal gland: T.P.P.-ase. Foveolar area. Strong activity is seen in the Golgi zone (G) of the abnormal gland cells. $\times 494$.

FIG. 10. Focal atrophic gastritis in normal gland. T.P.P.-ase. Foveolar area. Activity is virtually absent in the normal gland cells. 
genesis of atrophic gastritis. Wood and Taft (1958) summarized the available clinical information. There appears to be an inconstant association with age, malnutrition, alcoholism, and the female sex. Also, there is a relationship between atrophic gastritis and peptic ulcer, gastric carcinoma and certain types of anaemia (Hebbel, 1949; Wood and Taft, 1958; Cox, 1963). Once established, atrophic gastritis is irreversible (Wood and Taft, 1958; Floch, Thomassen, Cox, and Sheehy, 1963). There is considerable experimental evidence which suggests that atrophic gastritis may be caused by an autoimmune phenomenon (Hennes, Sevelius, Lewellyn, Joel, Woods, and Wolf, 1962; Irvine, Davies, Delamore, and Williams, 1962; DuVal, 1963; Taylor, Roitt, and Doniach, 1963; McKay, 1964; Adams, Glen, Kennedy, MacKenzie, Morrow, Anderson, Gray, and Middleton, 1964). From cytometric studies of the nucleus, Nieburgs and Glass (1963) have suggested that there is a 'maturation arrest' of the cells in atrophic gastritis. Teir and Räsänen (1961) reported intestinal metaplasia in 60 to $78 \%$ of the stomachs removed for gastric ulcer and gastric carcinoma. In this same group they found the mitotic rate of the pyloric mucosa to be twice as high as in the more normal stomachs of duodenal ulcer patients. Thus, the cell turnover appears to be rapid in the metaplastic epithelium.

The significance of the increased Golgi zone T.P.P.-ase activity in the cells of the atrophic gastritis glands is open to pure speculation. As yet, there is neither definite information about the biochemical role played by T.P.P.-ase nor electron microscopic confirmation of the exact location of the activity in these cells.

Histochemical observations on gastritis were first made by Wattenberg (1959) who reported that aminopeptidase was present in the metaplastic gastric mucosa but was absent from normal mucosa. Subsequently, Planteydt and Willighagen (1960) demonstrated a close histochemical resemblance between the atrophic gastritis mucosa and duodenal epithelium. They pointed out that in the brush border and Golgi zones of the metaplastic gastric mucosa there was an increase in a variety of enzymatic activities. These included alkaline phosphatase, aminopeptidase, 5-nucleotidase, A.T.P.-ase, esterase, and several oxidative enzymes. Niemi, Siurala, and Larmi (1961) also found the same distribution of oxidative enzymes in the metaplastic cells as in small bowel mucosa. Other investigators (Cornet, Bescol-Liversac, Guillam, and Debussche, 1962; Plosscowe, Berg, and Segal, 1963) subsequently confirmed the increased alkaline phosphatase activity in the brush border of the metaplastic epithelium.

The increased T.P.P.-ase activity which we noted was confined to the Golgi zones in the atrophic gastritis specimens and seemed to bear a quantitative relationship to the severity of the gastritis.

One can speculate that the increased enzymatic activity of the atrophic gastritis mucosa may represent a change in function from a primarily secretory mucosa to a primarily absorptive epithelium. Cox (1963) favours this hypothesis, since both cell turnover rateand the histochemically demonstrated enzymatic content of the metaplastic cells resemble those of the normal small intestine. Physiological and electron microscopic studies may elucidate this problem.

\section{SUMMARY}

Enzymatic histochemical techniques, which are said to demonstrate the lysosomes, the Golgi apparatus, and the mitochondria, were used to study human gastric mucosa. The enzymatic activities of the four major cell types of the normal corpus mucosa are summarized.

Although the 49 patients were selected because they had no known gastric disease, on histological examination $53 \%$ of them had moderate to severe gastritis. Among the clinical factors, only age correlated well with the severity of the gastritis.

The histochemical changes noted with atrophic gastritis seem directly related to the severity of the disease. A moderate increase in acid phosphatase activity was demonstrated by both the $\mathrm{PbS}$ and azodye methods whereas the $\mathrm{NADH}_{2}$ tetrazolium reductase activity was minimal in the atrophic glands. A marked increase in T.P.P.-ase activity was demonstrated in the foveolar mucous surface cells, both in the diffuse and focal gastritis.

The authors are grateful to the surgical resident staff, and to Mr. J. Diaz for their technical assistance. The photography was done by Mr. M. Kurtz.

This work was supported by grants from the Health Research Council of the City of New York (HRC U1183) and the National Institutes of Health (AN-03497).

\section{REFERENCES}

Adams, J. F., Glen, A. I. M., Kennedy, E. H., MacKenzie, I. L., Morrow, J. M., Anderson, J. R., Gray, K. G., and Middleton, D. G. (1964). The histological and secretory changes in the stomach in patients with autoimmunity to gastric parietal cells. Lancet, 1, 401-403.

Barka, T., and Anderson, P. J. (1963). Histochemistry. Theory, Practice and Bibliography, pp. 242-243. Harper and Row, New York.

Cornet, A., Bescol-Liversac, J., Guillam, C., and Debussche, C. (1962). Considérations histochimiques sur l'héteroplasie intestinale de la muqueuse gastrique chez l'homme. Ann. Histochim., 7 (3), 83-88.

Cox, A. J. (1963). Gastric mucosal changes in peptic ulcer. Gastroenterology, 45, 558-561.

DuVal, M. K. (1963). Role of vagus nerve in experimental production of atrophic gastritis. Amer. Surgr., 29, 183-185.

Essner, E., and Novikoff, A. B. (1960). Acid phosphatase activity in hepatic lysosomes: electron microscopic demonstration of its reaction product. J. Histochem. Cytochem., 8, 318. 
Floch, M. H., Thomassen, R. W., Cox, R. S., Jr., and Sheehy, T. W. (1963). The gastric mucosa in tropical sprue. Gastroenterology, $44,567-577$.

Gomori, G. (1950). An improved histochemical technic for acid phosphatase. Stain Technol., 25, 81-85.

Hebbel, R. (1949). The topography of chronic gastritis in otherwise normal stomachs. Amer. J. Path., 25, 125-141.

Hennes, A. R., Sevelius, H., Lewellyn, T., Joel, W., Woods, A. H., and Wolf, S. (1962). Atrophic gastritis in dogs. Arch. Path., 73, 281-287.

Irvine, W. J., Davies, S. H., Delamore, I. W., and Williams, A. W. (1962). Immunological relationship between pernicious anaemia and thyroid disease. Brit. med. J., 2, 454-456.

Lillie, R. D. (1954). Histopathologic Technique and Practical Histochemistry. 2nd ed., p. 118. Blakiston, New York.

McKay, I. R. (1964). Autoimmune serological studies in chronic gastritis and pernicious anaemia. Gut, 5, 23-26.

Nieburgs, H. E., and Glass, G. B., J. (1963). Gastric-cell maturation disorders in atrophic gastritis, pernicious anemia, and carcinoma. Amer. J. dig. Dis., 8, 135-159.

Niemi, M., Siurala, M., and Larmi, T. K. I. (1961). Histochemistry of three dehydrogenase systems in cancerous and non-cancerous human stomachs with special reference to intestinal metaplasia. Acta. path. microbiol., scand., 53, 139-146.

Novikoff, A. B. (1960). Biochemical and staining reactions of cytoplasmic constituents. In Developing Cell Systems and Their Control, (Society for the Study of Development and Growth18th symposium), edited by D. Rudnick, p. 188. Ronald Press Co., New York.
Novikoff, A. B. (1963). Personal communication.

and Goldfischer, S. (1961). Nucleosidediphosphatase activity in the Golgi apparatus and its usefulness for cytological studies. Proc. nat. Acad. Sci. (Wash.), 47, 802-810.

_-, Shin, W. Y., and Drucker, J. (1961). Mitochondrial localization of oxidative enzymes. Staining results with two tetrazolium salts. J. biophys. biochem. Cytol., 9, 47-61.

Planteydt, H. T., and Willighagen, R. G. J. (1960). Enzyme histochemistry of the human stomach with special reference to intestinal metaplasia. J. Path. Bact., 80, 317-323.

Plosscowe, R. P., Berg, G. G., and Segal, H. L. (1963). Enzyme histochemical studies of human gastric and jejunal biopsy specimens in normal and disease states. Amer. J. dig. Dis., 8, 311-318.

Ragins, H., Dittbrenner, M., and Diaz, J. (1964). Comparative histochemistry of the gastric mucosa: A survey of the common laboratory animals and man. Anat. Rec., 150, 179-193.

Taylor, K. B., Roitt, I., and Doniach, D. (1963). Gastric autoantibodies in pernicious anaemia. Gastroenterology, 44, 855 .

Teir, H., and Räsänen, T. (1961). A study of mitotic rate in renewal zones of non-diseased portions of gastric mucosa in cases of peptic ulcer and gastric cancer, with observations on differentiation and so-called 'intestinalization' of gastric mucosa. J. nat. Cancer Inst., 27, 949-971.

Wattenberg, L. W. (1959). Histochemical study of aminopeptidase in metaplasia and carcinoma of the stomach. Arch. Path., 67, 281-286.

Wood, I. J., and Taft, L. I. (1958). Diffuse Lesions of the Stomach. Edward Arnold, London. 